Check for updates

Cite this: RSC Adv., 2019, 9, 9373

\title{
Enhancement of the polymerase chain reaction by tungsten disulfide $\uparrow$
}

\author{
Dong Zhang, ${ }^{\text {ac }}$ Yingcun $\mathrm{Li}^{\text {a }}$ Xuange Zhang, ${ }^{\text {a }}$ Yongqiang Cheng $\mathbb{D}$ *a \\ and Zhengping $\mathrm{Li}(\mathbb{D}$ *ab
}

In this paper, we demonstrated that the polymerase chain reaction (PCR) could be dramatically enhanced by tungsten disulfide $\left(\mathrm{WS}_{2}\right)$. The results showed that the PCR efficiency could be increased with the addition of $\mathrm{WS}_{2}$ and at a lower annealing temperature, which simplified the design and operation of PCR. Moreover, PCR with $W_{2}$ showed better specificity and efficiency as compared with graphene oxide (GO) for a human genome DNA sample. The mechanism of enhancement of PCR by $W_{2}$ was discussed according to the typical structure and the characteristics of selective adsorption of single-stranded DNA by $W_{2}$. The results suggested that $W_{2}$ as a PCR enhancer can promote the PCR performance and extend the PCR application in biomedical research, clinical diagnostic, and bioanalysis.

Received 25th November 2018 Accepted 14th March 2019

DOI: $10.1039 / c 8 r a 09689 a$

rsc.li/rsc-advances nanomaterials as additives to optimize the PCR efficiency. ${ }^{14-18}$ Up to now, gold nanoparticles (AuNPs), graphene oxide (GO), quantum dots (QDs), carbon nanotubes (CNTs), and some other metal nanoparticles and nanocomposites have been used to improve the specificity and efficiency of the PCR. ${ }^{19-23}$ Although AuNPs can improve the specificity and efficiency of PCR, its own colour limited its application in some colorimetric reactions. ${ }^{24-27}$ GO and QDs can enhance the specificity of the PCR, the high dosage will, however, interfere with the detection of signals. ${ }^{28-32}$ Therefore, it is desired to further develop new materials for enhancing PCR.

Recently, the layered nanomaterials of transition metal sulfides, such as tungsten disulfide $\left(\mathrm{WS}_{2}\right)$ and molybdenum disulfide $\left(\mathrm{MoS}_{2}\right)$, had aroused great concern in many fields of science because of their unique optical and catalytic properties. ${ }^{33,34}$ It was discovered that $\mathrm{WS}_{2}$ could be synthesized in large scale and directly dispersed in aqueous solution as compared with GO that involved oxidation treatment, which might change the semiconductor properties of nanostructures. ${ }^{30}$ Therefore, $\mathrm{WS}_{2}$ showed great potential in biomedical applications. Yuan et al. established a simple ultrasonic assisted method to prepare water-soluble $\mathrm{WS}_{2}$ nanoscale and found that $\mathrm{WS}_{2}$ could adsorb ssDNA and quench the fluorescence of dye. ${ }^{35}$ The adsorbed ssDNA could leave $\mathrm{WS}_{2}$ nanoscale by interacting with other biomolecules, resulting in the recovery of fluorescence. More recently, Wang et al. reported that $\mathrm{MoS}_{2}$ and $\mathrm{WS}_{2}$ could enhance PCR signals owing to the adsorption of both the ssDNA PCR primers and DNA-staining dyes, SYBR Green I, with an appropriate strength. ${ }^{36}$ These discoveries enable $\mathrm{WS}_{2}$ to have more applications in the fields of biosensing and bioanalysis.

In this paper, we systematically studied the effects of $\mathrm{WS}_{2}$ concentration and annealing temperatures on PCR and demonstrated that the addition of $\mathrm{WS}_{2}$ within a certain
${ }^{a}$ Key Laboratory of Medicinal Chemistry and Molecular Diagnosis, Ministry of Education, Key Laboratory of Analytical Science and Technology of Hebei Province, College of Chemistry and Environmental Science, Hebei University, Baoding 071002, Hebei, P. R. China. E-mail: yqcheng@hbu.edu.cn; Fax: +86 312 5079403; Tel: +86 3125079403

${ }^{b}$ School of Chemistry and Biological Engineering, University of Science and Technology Beijing, Beijing, 100083, P. R. China.E-mail: lzpbd@ustb.edu.cn

${ }^{c}$ Sports Science Institute of Hebei Province, Shijiazhuang 050011, Hebei, P. R. China

$\dagger$ Electronic supplementary information (ESI) available. See DOI: 10.1039/c8ra09689a 
concentration range in the PCR system could significantly improve the efficiency and specificity of PCR at a lower annealing temperature. In addition, $\mathrm{WS}_{2}$ showed the better specificity and efficiency in PCR as compared with graphene oxide (GO), indicating that $\mathrm{WS}_{2}$ had the excellent performance in enhancing PCR, and the great potential for PCR-based bioassays and applications.

\section{Results and discussion}

\section{Characterization of the $\mathrm{WS}_{2}$}

The morphology of the used $\mathrm{WS}_{2}$ was characterized by transmission electron microscopy (TEM) and atomic force microscopy (AFM) as shown in Fig. 1. In the TEM image of the $\mathrm{WS}_{2}$ (Fig. 1a), the stacked, fragmented $\mathrm{WS}_{2}$ feature was observed. In the AFM images (Fig. 1b), the entire area of the individual

(a)
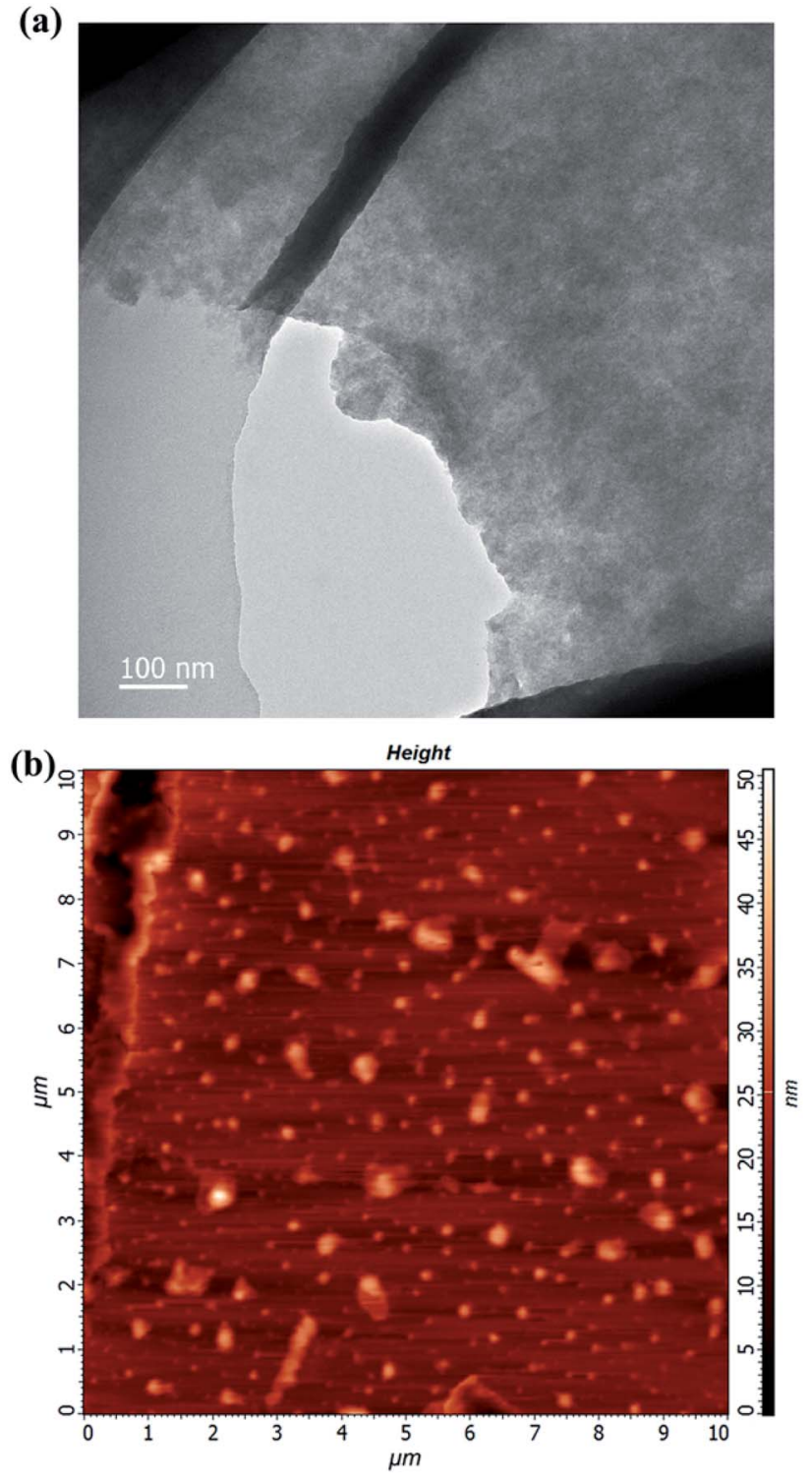

Fig. 1 Representative TEM image (a) and AFM image (b) of $\mathrm{WS}_{2}$ nanoscale. fragmented $\mathrm{WS}_{2}$ exhibited a uniform thickness. In particular, the size range of these $\mathrm{WS}_{2}$ sheets was nearly 50-500 $\mathrm{nm}$.

\section{Enhancement of PCR by $\mathrm{WS}_{2}$ with different concentration}

To demonstrate the ability of $\mathrm{WS}_{2}$ to enhance the PCR efficiency, we first analysed the PCR products by agarose gel electrophoresis by using the PCR to amplify the ACTN3 gene from the human genomic DNA with different concentrations of $\mathrm{WS}_{2}$. As shown in Fig. 2, the band intensities of the PCR products gradually increased with increasing $\mathrm{WS}_{2}$ concentration in the range from 0 to $5 \mu \mathrm{g} \mathrm{mL} \mathrm{m}^{-1}$, indicating that the amplification efficiency of PCR could be greatly improved by $\mathrm{WS}_{2}$. However, when the $\mathrm{WS}_{2}$ concentration was greater than $20 \mu \mathrm{g} \mathrm{mL}{ }^{-1}$, no PCR products could be detected (lane 12 and 13), suggesting that the PCR could be inhibited in the presence of a large amount of $\mathrm{WS}_{2}$. More importantly, the tailing bands could be obviously observed in PCR products in the absence of $\mathrm{WS}_{2}$, which indicated the non-specific PCR amplification. The nonspecific "tailing" bands could be gradually diminished with addition of $\mathrm{WS}_{2}$ in PCR and completely eliminated when the $\mathrm{WS}_{2}$ concentration was greater than $1 \mu \mathrm{g} \mathrm{mL}{ }^{-1}$. These results could demonstrate that the $\mathrm{WS}_{2}$ could effectively improve the PCR amplification efficiency and specificity. The concentration of $\mathrm{WS}_{2}$ was critical for obtaining optimal PCR results. The wide $\mathrm{WS}_{2}$ concentration range from $1 \mu \mathrm{g} \mathrm{mL}{ }^{-1}$ to $15 \mu \mathrm{g} \mathrm{mL}{ }^{-1}$ could be employed in this PCR system.

\section{Enhancement of PCR by $\mathrm{WS}_{2}$ at different annealing temperature}

In traditional PCR, the annealing temperature has a great influence on the specificity of PCR and the amplification efficiency. When the annealing temperature is too high, the primers and the template DNA cannot hybridize well, resulting in low amplification efficiency. Conversely, annealing temperature is too low, the primer would be non-specifically annealing with the template DNA, resulting in the non-specific amplification productions of DNA fragments. Therefore, we

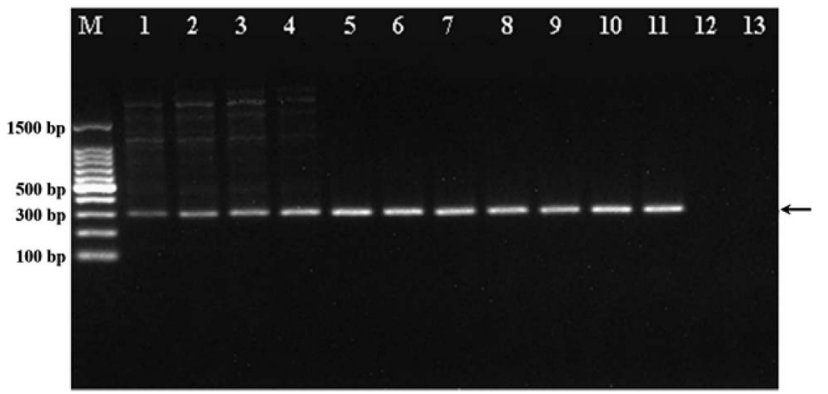

Fig. $2 W_{2}$ enhances PCR at different concentrations. Agarose gel images of marker and the amplified DNA bands with WS 2 or not. $10 \mu \mathrm{L}$ PCR system containing $13.7 \mathrm{ng}$ template DNA, $0.25 \mathrm{mM}$ of dNTPs, $200 \mathrm{nM}$ forward and reverse primers, $0.15 \mathrm{U}^{\mathrm{T}} \mathrm{Taq}^{\mathrm{TM}}$ Hot Star DNA polymerase. Lane $M$ was DNA marker. The final concentration of $\mathrm{WS}_{2}$ for lane 1 to lane 13 was $0,0.3,0.5,1,3,5,7,9,13,15,20,30,50 \mu \mathrm{g}$ $\mathrm{mL}^{-1}$, respectively. The arrows indicated the positions of the target DNA fragment. 
investigated the effect of $\mathrm{WS}_{2}$ on the PCR performance at different annealing temperature. Fig. 3 was the agarose electrophoretic image of the PCR products without the addition of $\mathrm{WS}_{2}$ (lanes 1-4) and with the addition of $\mathrm{WS}_{2}$ (lanes $1^{\prime}-4^{\prime}$ ), when the annealing temperature was $40,45,50$, and $55{ }^{\circ} \mathrm{C}$, respectively. As shown in Fig. 3, it could be seen there were many diffuse DNA bands for PCR products and the specific $291 \mathrm{bp}$ band of PCR products could not be observed in the lane 1 and lane 2, indicating that in the absence of $\mathrm{WS}_{2}$, no specific PCR products could be detected at lower annealing temperature $\left(40{ }^{\circ} \mathrm{C}\right.$ and $\left.45^{\circ} \mathrm{C}\right)$. On the other hand, the bands of specific PCR products (291 bp) could be obviously observed with addition of $\mathrm{WS}_{2}$ at the lower annealing temperature (lane $1^{\prime}$ and lane $2^{\prime}$ ). Moreover, at the same annealing temperature, the band of specific PCR products by addition of $\mathrm{WS}_{2}$ (lane $3^{\prime}$ ) were much brighter than that in the absence of $\mathrm{WS}_{2}$ (lane 3 ). These results indicate that the addition of $\mathrm{WS}_{2}$ in PCR can greatly enhance the PCR amplification specificity and efficiency even at a lower annealing temperature, which suggests that $\mathrm{WS}_{2}$ makes the PCR very suitable for wide annealing temperature and facilitates the application of PCR.

Moreover, to further prove the enhancement effects of $\mathrm{WS}_{2}$ on PCR, we investigated the PCR with the varied lengths of the PCR products and the other DNA polymerase (Fig. S1 $\dagger$ ). The same enhancement effects of $\mathrm{WS}_{2}$ on PCR as Taq DNA polymerase were observed with the different lengths of PCR products and Phusion DNA polymerase, where annealing temperature optimization was not successful without $\mathrm{WS}_{2}$.

To investigate the effect of $\mathrm{WS}_{2}$ on the fidelity of DNA polymerase, the PCR products of $291 \mathrm{bp}$ without and with $\mathrm{WS}_{2}$ were sequenced by Sanger sequencing. The sequencing result showed that the sequences of the PCR products with $\mathrm{WS}_{2}$ were identical to those without $\mathrm{WS}_{2}$, indicating that the addition of $\mathrm{WS}_{2}$ would not affect the fidelity of DNA polymerase (Fig. S2 and Table S1†).

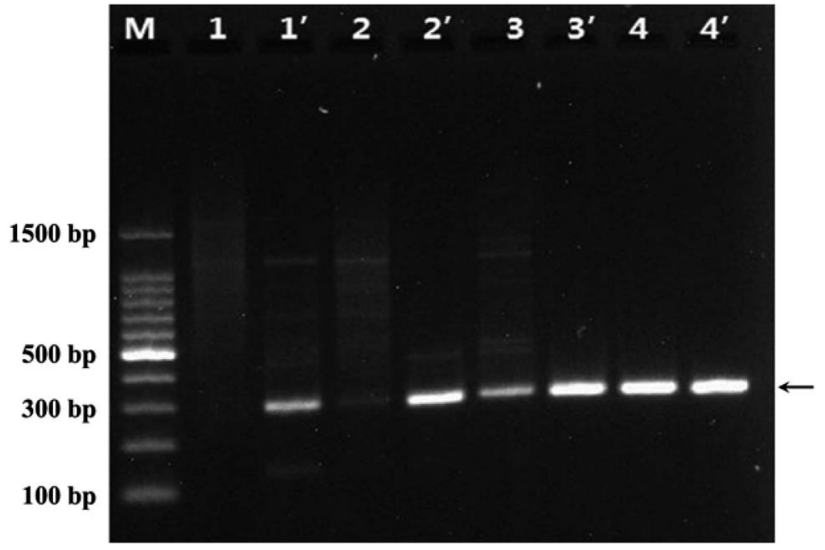

Fig. 3 Agarose gel images of $W_{2}$ effect on PCR under the different annealing temperature. Lane $M$ was DNA marker. Lane 1 to lane 4 without the $\mathrm{WS}_{2}$, lane $1^{\prime}$ to lane $4^{\prime}$ was added $5 \mu \mathrm{g} \mathrm{mL} \mathrm{L}^{-1} \mathrm{WS}_{2}$. The annealing temperature of PCR for lane $1 / 1^{\prime}$ to lane $4 / 4^{\prime}$ was $40,45,50$, $55{ }^{\circ} \mathrm{C}$, respectively. The arrows indicated the positions of the target DNA fragment. The experiment conditions were the same as Fig. 2.

\section{Effect on the PCR efficiency with $\mathrm{WS}_{2}$ by real-time PCR assays}

The effect of $\mathrm{WS}_{2}$ on the PCR efficiency was also investigated by real-time quantitative PCR by using SYBR Green I as the fluorescence dye (Fig. 4). In this case, relative fluorescence intensity was directly associated with the yield of the PCR products in response to the $\mathrm{WS}_{2}$. Compared to the control assay without the addition of $\mathrm{WS}_{2}$ in PCR, the PCR efficiency for genomic DNA was obviously enhanced in the presence of the $\mathrm{WS}_{2}$. In particular, the efficiency produced by the $\mathrm{WS}_{2}$ was about 1.8 times higher than that of the control. Therefore, the $\mathrm{WS}_{2}$ shows great enhancement for PCR efficiency in both the conventional PCR and real-time fluorescence PCR, suggesting the great potential of $\mathrm{WS}_{2}$ enhancement for real-time quantitative PCR.

\section{Comparison of the effects of $\mathrm{WS}_{2}$ and GO on PCR}

It has been reported that GO can be used as an excellent additive to enhance the PCR amplification efficiency and specificity. ${ }^{37} \mathrm{WS}_{2}$ is similar to GO as the layered two-dimension nanomaterials. Therefore, we compared the enhancement efficiency for PCR between $\mathrm{WS}_{2}$ and GO. As shown in Fig. 5a, in the absence of $\mathrm{WS}_{2}$ and GO, the band of PCR producers were weaker and many non-specific amplification products could be detected. When the $\mathrm{WS}_{2}$ or GO were respectively added into PCR in the concentration ranging from 0.3 to $1 \mu \mathrm{g} \mathrm{mL}{ }^{-1}$, the band densities of the PCR products were significantly increased with increasing the concentration of $\mathrm{WS}_{2}$ or GO and the non-specific bands were gradually reduced. At the same time, it could be seen from Fig. $5 \mathrm{~b}$, the band densities of $\mathrm{WS}_{2}$-enhanced PCR products was higher than those of GO-enhanced PCR. More importantly, when the $\mathrm{WS}_{2}$ concentration was greater than $3 \mu \mathrm{g}$ $\mathrm{mL}^{-1}$, the band densities of the $\mathrm{WS}_{2}$-enhanced PCR products reached their maximum and the non-specific bands could be completely eliminated. In contrast, when the GO concentration was greater than $3 \mu \mathrm{g} \mathrm{mL} \mathrm{m}^{-1}$, the PCR could be inhibited so that no PCR products could be detected. These results demonstrated that $\mathrm{WS}_{2}$ showed significantly higher enhancement than GO for PCR amplification efficiency and $\mathrm{WS}_{2}$ could be employed at

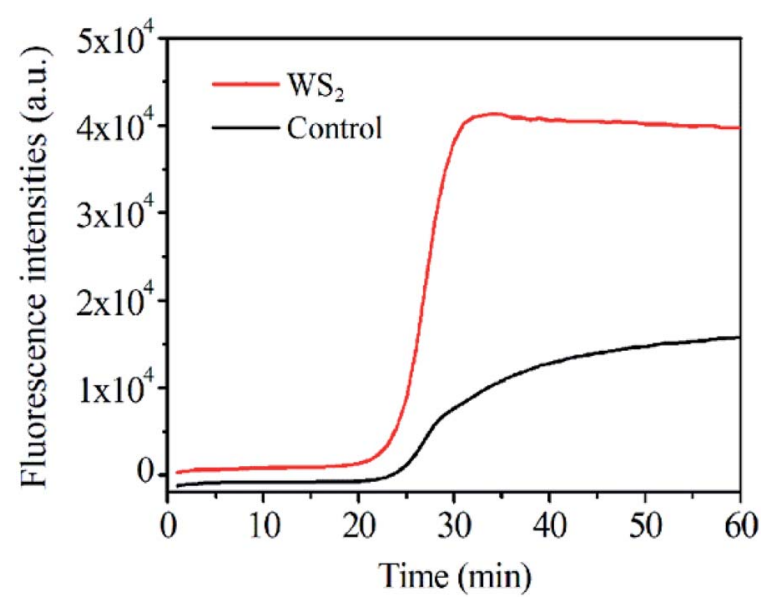

Fig. 4 Different amount $\mathrm{WS}_{2}$ effect on fluorescence intensity of realtime PCR assays, the final concentration of $\mathrm{WS}_{2}$ was 0 and $5 \mu \mathrm{g} \mathrm{mL}^{-1}$. 


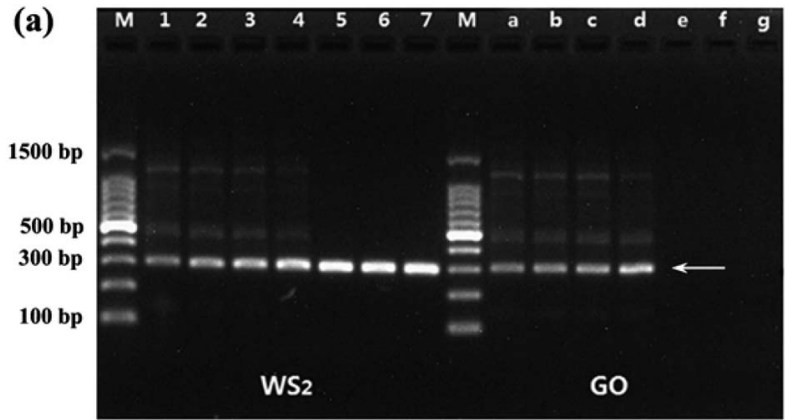

(b)

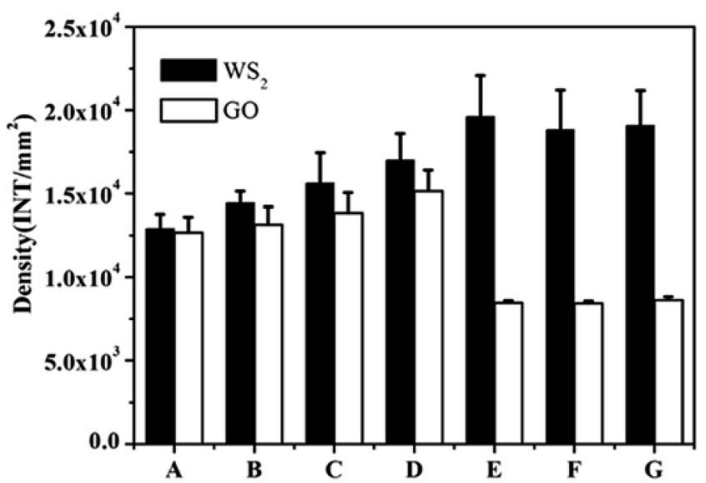

Fig. 5 Comparison of the enhancement effects of $\mathrm{WS}_{2}$ and $\mathrm{GO}$ on PCR. (a) Lane $M$ was marker. The final concentration of $W_{2}$ for lane 1 to lane 7 was $0,0.3,0.5,1,3,5,7 \mu \mathrm{g} \mathrm{mL}^{-1}$, the final concentration of $\mathrm{GO}$ for lane a to lane $\mathrm{g}$ was $0,0.3,0.5,1,3,5,7 \mu \mathrm{g} \mathrm{mL}^{-1}$. The arrows indicated the positions of the target DNA fragment. (b) A-G is the optical density of $\mathrm{WS}_{2} / \mathrm{GO}$ at concentrations of $0,0.3,0.5,1,3,5$ and 7 $\mu \mathrm{g} \mathrm{mL} \mathrm{m}^{-1}$, respectively. The experiment conditions were the same as Fig. 2

high concentration in PCR to achieve the optimized amplification efficiency and specificity.

\section{The mechanism of enhancement of PCR by $\mathrm{WS}_{2}$}

Owing to their unique structure and physicochemical properties, nanoparticles have been shown to be effective in suppressing nonspecific amplification and improving the sensitivity of PCR. ${ }^{38}$ Moreover, the relevant mechanisms of PCR enhanced by various nanoparticles, such as AuNPs and GO et al. have been studied. ${ }^{39}$ Similarly, the mechanism of enhancement

(a)

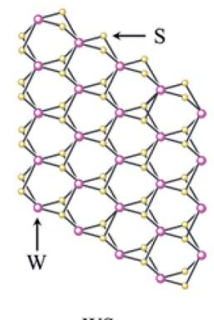

$\mathrm{WS}_{2}$

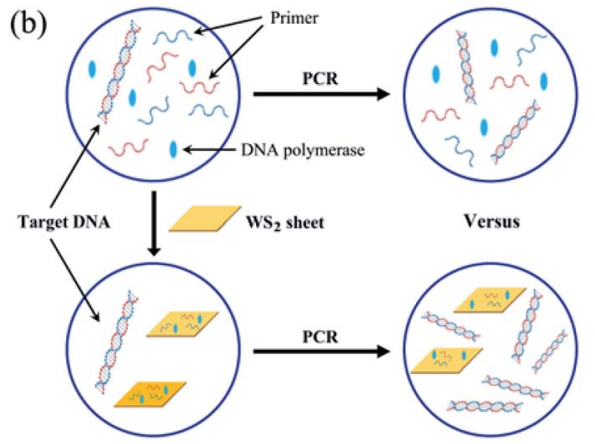

(b)

Fig. 6 Schematic illustration of $\mathrm{WS}_{2}$ enhanced PCR verification. of PCR by $\mathrm{WS}_{2}$ is closely related to its structure and photophysical property. As shown in Fig. $6 \mathrm{a}, \mathrm{WS}_{2}$ has a twodimensional (2D) graphene-like layered structure and the layers are bound by a weak van der Waals force. Each tungsten atom is surrounded by six sulfur atoms and the tungsten atoms and sulfur atoms are covalently bonded to form a twodimensional crystal material with a sandwich structure. ${ }^{36}$ Accordingly, the typical layered structure of $\mathrm{WS}_{2}$ endows it some unique properties for enhancement of PCR as follows.

It was reported that $\mathrm{WS}_{2}$ had the ability to selectively adsorb ssDNA because the similar structure and properties of $\mathrm{GO}^{40}$ Thus, in the denaturation stage of PCR, forward and reverse primers (ssDNA) can be adsorbed on the surface of $\mathrm{WS}_{2}$ by noncovalent binding. In the annealing stage of PCR, forward and reverse primers can hybridize with template DNA to form double strands so as to escape from the surface of $\mathrm{WS}_{2}$. In this way, a dynamic equilibrium process of adsorption and desorption may be formed between ssDNA primers and $\mathrm{WS}_{2}$, which reduces the mismatch probability between the primers and the DNA template at the annealing stage, thus reducing the primers dimer formation and improving the specificity of PCR. In addition, $\mathrm{WS}_{2}$ may absorb DNA polymerase for the enhancement of the PCR on the basis of the adsorption and desorption kinetic mechanism. Similar to the interaction between ssDNA$\mathrm{WS}_{2}$, the polarity group on the amino acid structure of the polymerase is positively charged, so there is a tendency to be adsorbed by $\mathrm{WS}_{2}$. On the other hand, the side chain of protein does not contain polar groups, indicating that it is not completely adsorbed by $\mathrm{WS}_{2}$. These results can affect the activity of DNA polymerase in the PCR system so as to reduce the generation of nonspecific amplification and enhance the amplification efficiency of the PCR.

Because the metal centre of $\mathrm{WS}_{2}$ is sandwich and there is no direct interaction with DNA, the interaction between $\mathrm{WS}_{2}$ and ssDNA may be van der Waals force. ${ }^{41} \mathrm{GO}$ absorbing DNA mainly depends on hydrogen bonding and van der Waals force, which is stronger than that of $\mathrm{WS}_{2}$. Therefore, in the thermal cycle of PCR, ssDNA primer is easier to desorption from $\mathrm{WS}_{2}$ than GO. Thus, the high desorption efficiency of primers from $\mathrm{WS}_{2}$ results in better enhancement of PCR by $\mathrm{WS}_{2}$ than GO in Fig. 5 .

\section{Conclusions}

In this work, we have demonstrated that $\mathrm{WS}_{2}$ with the layered structure can significantly improve the amplification efficiency with the more PCR products and specificity of PCR by reducing the nonspecific bands. Furthermore, the $\mathrm{WS}_{2}$ nanomaterials have the better enhancement effect for PCR amplification than GO. More importantly, the $\mathrm{WS}_{2}$ can be employed in PCR in the wide concentration and temperature ranges, which make the PCR very facile performance under mild conditions and may avoid the strict optimization of experiment condition of PCR. Even in the conventional PCR, when optimization of annealing temperature is not successful to improve the specificity of PCR, the significant enhancement effect can be achieved by adding $\mathrm{WS}_{2}$ nanosheets to the PCR. Therefore, the $\mathrm{WS}_{2}$-based enhancement PCR can effectively extend the PCR applications 
and has great potential in molecular biology, genetic analysis, biomedical research, and clinical diagnosis, etc. At the same time, this work provides a new idea for studying the application of two-dimensional nanomaterials in the other nucleic acid amplification technologies.

\section{Experimental}

\section{Materials and reagents}

Taq $^{\text {TM }}$ Hot Start DNA Polymerase, DNA marker, loading buffer were purchased from Takara Biotechnology Co., Ltd (Dalian, China). Tungsten disulfide $\left(\mathrm{WS}_{2}\right)$ nanosheet dispersion with $\mathrm{LiOH}$ (single layer ratio $\geq 90 \%$ ) and Graphene oxide (GO) were purchased from Nanjing XF Nano Material Tech Co., Ltd. (Nanjing, China). Agarose was obtained from Sangon Biotech Co., Ltd. (Shanghai, China). GelGreen was obtained from Biotium Co., Ltd. (California, USA). Genomic DNA was extracted from human blood by using TIANamp Genomic DNA Kit (TIANGEN Biotechnology, China). All chemical reagents were of analytical reagent grade and all solutions were prepared with ultrapure water. The sequences of oligonucleotides used in this work were listed below, which were synthesized and purified by TaKaRa Biotechnology Co. Ltd. (Dalian, China).

PCR Primer F: CTGTTGCCTGTGGTAAGTGGG

PCR Primer R: TGGTCACAGTATGCAGGAGGG

\section{Characterization of $\mathrm{WS}_{2}$ nanosheet}

A small amount of $\mathrm{WS}_{2}$ nanosheet solution was dispersed evenly with ultrasonic for $10 \mathrm{~min}$. Then it was diluted to light yellow with deionized water. Subsequently, about $2 \mu \mathrm{L}$ solution was dropped onto a micro grid for transmission electron microscopy (TEM) analysis with Tecnai G2 F20 (FEI, Hillsboro, USA).

A small amount of $\mathrm{WS}_{2}$ nanosheet solution was diluted to a light yellow color, and then dispersed it with ultrasonic for $10 \mathrm{~min}$. After that, about $2 \mu \mathrm{L}$ of $\mathrm{WS}_{2}$ nanosheet solution was dropped onto a new mica sheet and dried naturally for atomic force microscope (AFM) characterization with non-contact mode on Dimension Icon (BRUKER, Massachusetts, USA).

\section{Extraction of genomic DNA}

The human genome DNA was obtained from peripheral blood samples of athlete volunteers and extracted by using TIANamp Genomic DNA Kit (TIANGEN Biotechnology). The concentration of the extracted genomic DNA was measured by NanoDrop ${ }^{\mathrm{TM}}$ One spectrophotometer (Thermo Fisher Scientific Co. Ltd) at $260 \mathrm{~nm}$.

\section{Polymerase chain reaction}

In the model PCR system, the forward primer and reverse primer were used to amplify a $291 \mathrm{bp}$ fragment from the human genomic DNA of ACTN3 gene (rs1815739 SNP site.) as target sequence. The reaction was performed in a $10 \mu \mathrm{L}$ mixture containing $13.7 \mathrm{ng} \mu \mathrm{L}^{-1}$ of genomic DNA, $0.25 \mathrm{mM}$ of dNTPs, $200 \mathrm{nM}$ of forward and reverse primers, $1 \mu \mathrm{L}$ of Taq ${ }^{\mathrm{TM}}$ Hot Start DNA Polymerase buffer (10 mM Tris- $\mathrm{HCl}$ pH 8.3, $50 \mathrm{mM} \mathrm{KCl,}$
1.5 $\mathrm{mM} \mathrm{MgCl}_{2}$ ), $0.15 \mathrm{U}$ of $\mathrm{Taq}^{\mathrm{TM}}$ Hot Start DNA Polymerase, and different concentrations of $\mathrm{WS}_{2}$ nanomaterials with ultrasonic for $10 \mathrm{~min}$. The PCRs were carried out in the 2720 thermal cycler (Applied Biosystems, USA), with the program of hot start at the $98{ }^{\circ} \mathrm{C}$ for $10 \mathrm{~s}$, and $50{ }^{\circ} \mathrm{C}$ for $30 \mathrm{~s}, 72{ }^{\circ} \mathrm{C}$ for $1 \mathrm{~min}$ for 35 reaction cycles.

\section{Agarose gel electrophoresis}

After the amplification, the PCR products were further analyzed by $2.2 \%$ agarose gel electrophoresis. Electrophoresis was performed in $1 \times$ TAE buffer solution, under $110 \mathrm{~V}$ voltage for $40 \mathrm{~min}$, and then used to perform imaging with the VersaDoc Model 4000 gel imager (Bio-Rad, USA). The performance of nanomaterials for amplification and analysis of product was confirmed via the band intensities using gel documentation system and quantified by Image $\mathrm{J}$.

\section{Real-time PCR amplification}

Real-time PCR was performed in $10 \mu \mathrm{L}$ aqueous solution containing $0.2 \mu \mathrm{L}$ of Takara Ex Taq HS, $10 \times$ PCR buffer $(100 \mathrm{mM}$ Tris-HCl, $\mathrm{pH}=8.9,500 \mathrm{mM} \mathrm{KCl}, 15 \mathrm{mM} \mathrm{MgCl}_{2}$ ), $1 \mu \mathrm{L}$ of $2.5 \mathrm{mM}$ each of the dNTPs, $0.2 \mu \mathrm{L}$ of $20 \times$ SYBR Green I, $1 \mu \mathrm{L}$ of $10 \mathrm{pM}$ each of forward and reverse primers, $1 \mu \mathrm{L}$ DNA genome DNA and $3.8 \mu \mathrm{L}$ of $\mathrm{H}_{2} \mathrm{O}$. The mixture solution was initial denaturation at $94{ }^{\circ} \mathrm{C}$ for $4 \mathrm{~min}$, and was followed by 50 cycles of $98{ }^{\circ} \mathrm{C}$ for $10 \mathrm{~s}, 50{ }^{\circ} \mathrm{C}$ for $30 \mathrm{~s}, 72{ }^{\circ} \mathrm{C}$ for $1 \mathrm{~min}$ in StepOne $\mathrm{TM}^{\mathrm{TM}}$ Real-Time PCR System.

\section{Conflicts of interest}

There are no conflicts of interest to declare.

\section{Acknowledgements}

The authors are grateful for the financial support of the National Natural Science Foundation of China (No. 21075028 and 21475031).

\section{Notes and references}

1 K. Mullis, F. Faloona, S. Scharf, R. Saiki, G. Horn and H. Erlich, Cold Spring Harbor Symp. Quant. Biol., 1986, 51, 263.

2 C. Ding and C. R. Cantor, Proc. Natl. Acad. Sci. U. S. A., 2003, 100, 7449.

3 M. Filteau, L. Lagace, G. LaPointe and D. Roy, Syst. Appl. Microbiol., 2010, 33, 165.

4 M. R. Tiba, C. de Moura, M. F. Carazzolle and D. D. S. Leite, Braz. J. Infect. Dis., 2011, 15, 144.

5 K. Satoh, M. Maeda, Y. Umeda, Y. Miyajima and K. Makimura, Microbiol. Immunol., 2011, 55, 454.

6 J. H. Lu, H. K. Li, H. J. An, G. H. Wang, Y. Wang, M. Q. Li, Y. Zhang and J. Hu, J. Am. Chem. Soc., 2004, 126, 11136.

7 S. Kwok and R. Higuchi, Nature, 1989, 339, 237.

8 S. Yang and R. E. Rothman, Lancet Infect. Dis., 2004, 4, 337. 
9 Z. Strezoska, A. Licon, J. Haimes, K. J. Spayd, K. M. Patel, K. Sullivan, K. Jastrzebski, K. J. Simpson, D. Leake, A. van B. Smith and A. Vermeulen, PLoS One, 2012, 7, e42341.

10 M. Niens, G. T. Spijke, A. Diepstra and G. J. te Meerman, Biotechnol. Appl. Biochem., 2005, 42, 157.

11 M. A. Jensen, M. Fukushima and R. W. Davis, PLoS One, 2010, 5, e11024.

12 G. Sarkar, S. Kapelner and S. S. Sommer, Nucleic Acids Res., 1990, 18, 7465.

13 Q. Chou, Nucleic Acids Res., 1992, 20, 4371.

14 A. E. Nel, L. Mädler, D. Velegol, T. Xia, E. M. V. Hoek, P. Somasundaran, F. Klaessig, V. Castranova and M. Thompson, Nat. Mater., 2009, 8, 543.

15 A. Li, B. Zhou, C. S. Alves, B. Xu, R. Guo, X. Y. Shi and X. Y. Cao, ACS Appl. Mater. Interfaces, 2016, 8, 25808.

16 J. Y. Park, S. H. Back, S. J. Chang, S. J. Lee, K. G. Lee and T. J. Park, ACS Appl. Mater. Interfaces, 2015, 7, 15633.

17 Y. Bai, Y. Cui, G. C. Paoli, C. Shi, D. Wang and X. Shi, ACS Appl. Mater. Interfaces, 2015, 7, 13142.

18 E. Vanzha, T. Pylaev, V. Khanadeev, S. Konnova, V. Fedorova and N. Khlebtsov, RSC Adv., 2016, 6, 110146.

19 X. Lou and Y. Zhang, ACS Appl. Mater. Interfaces, 2013, 5, 6276.

20 S. H. Hwang, S. G. Im, S. S. Hah, V. T. Cong, E. J. Lee, Y. S. Lee, G. K. Lee, D. H. Lee and S. J. Son, PLoS One, 2013, 8, e73408.

21 R. M. Williams, S. Nayeem, B. D. Dolash and L. J. Sooter, PLoS One, 2014, 9, e94117.

22 R. Abdul Khaliq, P. J. Sonawane, B. K. Sasi, B. S. Sahu, T. Pradeep, S. K. Das and N. R. Mahapatra, Nanotechnology, 2010, 21, 255704.

23 W. Tong, X. Cao, S. Wen, R. Guo, M. Shen, J. Wang and X. Shi, Int. J. Nanomed., 2012, 7, 1069.

24 X. Liu, Q. Dai, L. Austin, J. Coutts, G. Knowles, J. Zou, H. Chen and Q. Huo, J. Am. Chem. Soc., 2008, 130, 2780.
25 U. H. F. Bunz and V. M. Rotello, Angew. Chem., Int. Ed., 2010, 49, 3268.

26 P. Chen, D. Pan, C. Fan, J. Chen, K. Huang, D. Wang, H. Zhang, Y. Li, G. Feng, P. Liang, L. He and Y. Shi, Nat. Nanotechnol., 2011, 6, 639.

27 S. Pathak, S. K. Choi, N. Arnheim and M. E. Thompson, J. Am. Chem. Soc., 2001, 123, 4103.

28 G. Liang, C. Ma, Y. Zhu, S. Li, Y. Shao, Y. Wang and Z. Xiao, Nanoscale Res. Lett., 2011, 6, 51.

29 H. Shen, M. Hu and Z. Yang, Chin. Sci. Bull., 2013, 50, 2016. 30 L. Liu, J. Zhang, J. Zhao and F. Liu, Nanoscale, 2012, 4, 5910. 31 S. Li, A. N. Aphale, I. G. Macwan, P. K. Patra, W. G. Gonzalez, J. Miksovska and R. M. Leblanc, ACS Appl. Mater. Interfaces, 2012, 4, 7069.

32 A. Splendiani, L. Sun, Y. Zhang, T. Li, J. Kim, C. Y. Chim, G. Galli and F. Wang, Nano Lett., 2010, 10, 1271.

33 D. Voiry, H. Yamaguchi, J. Li, R. Silva, D. C. Alves, T. Fujita, M. Chen, T. Asefa, V. B. Shenoy, G. Eda and M. Chhowalla, Nat. Mater., 2013, 12, 850.

34 C. Zhu, Z. Zeng, H. Li, F. Li, C. Fan and H. Zhang, J. Am. Chem. Soc., 2013, 135, 5998.

35 Y. X. Yuan, R. Q. Li and Z. H. Liu, Anal. Chem., 2014, 86, 3610. 36 L. Wang, Z. Huang, R. Wang, Y. Liu, C. Qian, J. Wu and J. Liu, ACS Appl. Mater. Interfaces, 2018, 10, 4409.

37 J. Jia, L. Sun, N. Hu, G. Huang and J. Weng, Small, 2012, 8, 2011.

38 M. Yuce, H. Kurt, V. R. S. S. Mokkapati and H. Budak, RSC $A d v ., 2014$, 4, 36800.

39 W. C. Yang, X. H. Li, J. L. Sun and Z. F. Shao, ACS Appl. Mater. Interfaces, 2013, 5, 11520.

40 Q. Xi, D. M. Zhou, Y. Y. Kan, J. Ge, Z. K. Wu, R. Q. Yu and J. H. Jiang, Anal. Chem., 2014, 86, 1361.

41 R. Guo, Y. D. Jho and A. J. Minnich, Nanoscale, 2018, 10, 14432. 